\title{
REGULARARTICLE
}

\section{EXPLOITATION OF SOMACLONAL VARIABILITY FOR THE SEARCH OF SALIN- TOLERANT POTATO (SOLANUM TUBEROSUM L.)}

\section{BENDIF HAMDI 1,2* , LAZALI MOHAMMED, MESSAOUDI NOURA², GHADBANE MOULOUD², KHENIFI MOHAMED-AMINE ${ }^{1}$, KADRI FARIDA ${ }^{1}$, BOUDJENIBA MESSAOUD ${ }^{1}$}

${ }^{1}$ Laboratoire d'Ethnobotanique et de Substances Naturelles, Département des Sciences Naturelles, Ecole Normale Supérieure (ENS), Kouba, Alger, Algérie

${ }^{2}$ Département des Sciences de la Nature et de la Vie, Faculté des Sciences, Université Mohamed Boudiaf, BP 166 Msila 28000, Msila, Algeria

3Université de Khemis Miliana, Faculté des Sciences de la Nature et de la Vie and des Sciences de la Terre, Route Theniet El Had, Soufay 44225 Ain Defla, Algeria

\begin{abstract}
The present investigation was conducted with an aim to study the effect of salt stress $(\mathrm{NaCl})$ on in vitro potato callus growth and the potential for exploiting this technique in improving salinity tolerance in potato. The results in the four varieties in the culture medium showed a decrease in all studied parameters like callus growth, relative average growth, water content and salinity sensitivity coefficient upon increasing the salinity of the medium in calluses. It has also been observed that the type of callus has a large effect on the above-mentioned parameters in which better callus growth adapted to $150 \mathrm{mmol} \mathrm{NaCl}$ is obtained than unsuitable calli in the same culture medium.
\end{abstract}

Keywords: Callogenesis, Potato (Solanum tuberosum L.), Salinity, Somaclonal Variations

\section{INTRODUCTION}

The potato (Tuberosum solanum L.) from the Solanaceae family is one of the most widely used crops in the world, and is the fourth most important food crop after rice, wheat and maize [1]. Sustained improvements in production will be needed to meet the needs of the rapidly growing population in a changing environment. In Algeria, the massive influx of chemical fertilizers and irrigation with brackish water constitute a major constraint for the development of the potato. Improving the tolerance of food plants to salinity, such as potatoes, becomes necessary for the exploitation of saline, natural or salt soils by local irrigation operations [2].

Genetic breeding by conventional selection of crosses to obtain salinity-tolerant genotypes is a relatively difficult approach to apply because of the time required [3]. On the other hand, in vitro culture selection may be a promising way to improve the tolerance of this species to salt stress, as this biotechnological approach has been used successfully in the selection of salt stress tolerant genotypes in several species.

In the field of biotechnology for crop improvement, in vitro culture is a key technique [4], especially for somaclonal variation, which is a phenomenon that leads to phenotypic variation of regenerated from in vitro culture $[5,6]$. These variations can occur in isolated protoplasts or calli [7]. The purpose of this article is to study the effect of salt stress $(\mathrm{NaCl})$ on in vitro potato callus growth and the potential for exploiting this technique in improving salinity tolerance in this potato species.

\section{Matériel et méthodes}

Our experiment took place in the SAGRODEV laboratory (Société AGRO Developement) in Sétif (Algeria). The starting plant material was supplied to us as healthy tubers by SAGRODEV. These tubers consist of four varieties namely: Désirée, Spunta Bartina and Kondor, two types of explant (leaves and internode) resulting from these varieties.

\section{Initiation of callogenesis}

The sprouts are disinfected with alcohol at $70{ }^{\circ}$ for 5 seconds, then with $\mathrm{HgCl} 2$ solution for 20 min and finally transplanted under sterile conditions onto a Murashige and Skoog (MS) medium [8]. Until in vitro plant are obtained.

For the induction of callogenesis, the explants (leaves and internodes taken from microplant) are cultivated in the callogenesis medium $\mathrm{MS}$, containing (5 mg/L NAA+1

\footnotetext{
Received 11 November 2017; Accepted 31 December 2017

*Corresponding Author

\section{Bendif Hamdi}

Laboratoire d'Ethnobotanique et de Substances Naturelles, Département des Sciences Naturelles, Ecole Normale Supérieure (ENS), Kouba, Alger, Algérie

Email: bendif_hamdi@yahoo.fr

( $T$ This article is open access and licensed under the terms of the Creative Commons Attribution License (http://creativecommons.org/licenses/by/4.o/) which permits unrestricted, use, distribution and reproduction in any medium, or format for any purpose, even commercially provided the work is properly cited. Attribution - You must give appropriate credit, provide a link to the license, and indicate if changes were made. 
$\mathrm{mg} / \mathrm{L} \mathrm{BAB}+1 \mathrm{mg} / \mathrm{L} \mathrm{GA} 3)$.

The $\mathrm{pH}$ is adjusted to 5.6-5.8 before autoclaving for 20 min at $120^{\circ} \mathrm{C}$. Culture was kept for $30 \mathrm{~d}$ in a growth room at $25 \pm 2{ }^{\circ} \mathrm{C}$ having $1.83 \mathrm{~m}$ fluorescent tubes and was illuminated $16 \mathrm{~h}$ daily with a light intensity of 1500 lux.

\section{Adaptation of callus to salinity}

The calli are adapted to the different concentrations of $\mathrm{NaCl}(00 ; 50 ; 100$ and $150 \mathrm{~g} / \mathrm{L})$, added to the MS medium, supplemented with different concentrations of phytohormones (the same medium for initiation of callogenesis). The calli are cultivated under the same conditions of callogenesis.

\section{RESULTS}

The callus begins to form on one side of the internode segment and then generalizes to the explant, suggesting a certain polarity of callogenesis. Fig. 1, shows that in the absence of $\mathrm{NaCl}$, almost, all the explants form calluses between 72 and $95 \%$. The presence of $\mathrm{NaCl}(50 \mathrm{mmol})$ slows the callogenesis, without much altering its final rate which is between 68 and 95\%. And finally the presence of $\mathrm{NaCl}(150 \mathrm{mmol})$ considerably slows the callogenesis, which is between 10 and $30 \%$.

In general, a decrease in callogenesis with increasing $\mathrm{NaCl}$ concentration in the culture medium is recorded.

The results obtained for the type and color of the callus at the different concentrations of $\mathrm{NaCl}$ are shown in fig. 2. The calli are transparent and compact for the variety Desiree, friable and yellowish for Spunta but, for Bartina they are compact, green and transparent while they are compact for Kondor.

In the presence of $\mathrm{NaCl}$, the calli are light green in color and have a slight brownish discolouration (fig. 2).

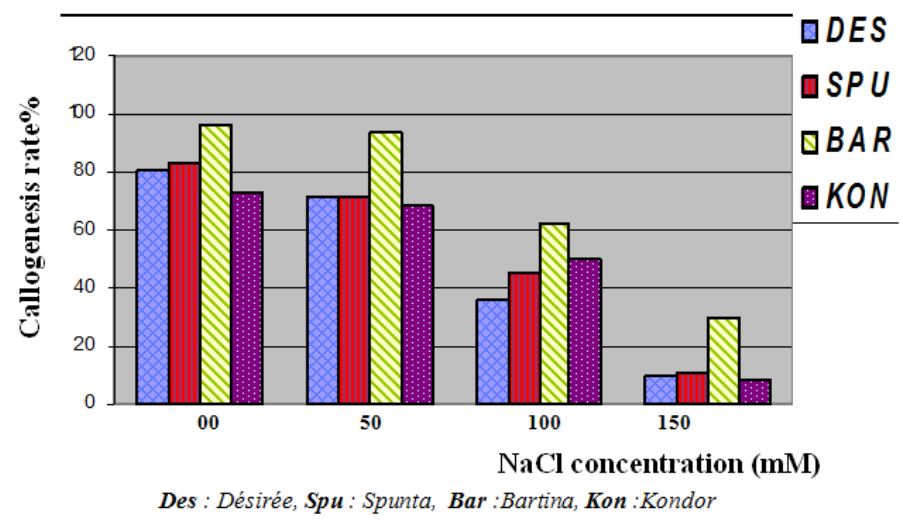

Fig. 1: Effect of $\mathrm{NaCl}$ on the rate of callogenesis in four potato varieties (Désirée, Spunta, Bartina, Kondor)
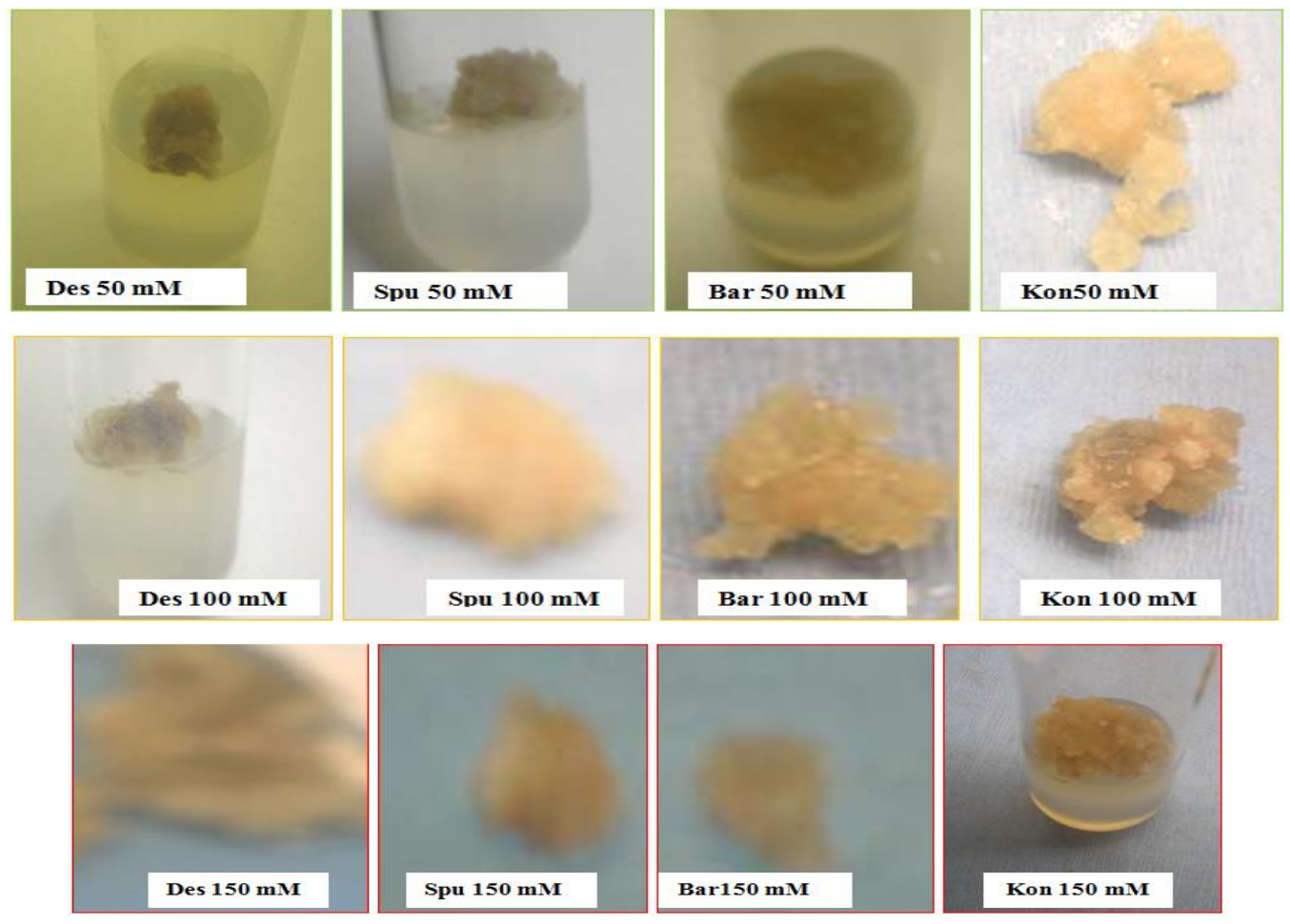

Des: Désirée, Spu: Spunta, Bar: Bartina, Kon: Kondor

Fig. 2: Cals obtained after gradual selection in the saline environment for four varieties of potato: Désirée, Spunta, Bartina, Kondor 
For growth of calli not adapted to salinity, at different concentrations of $\mathrm{NaCl}$, the rate of decrease in fresh and dry weight is mentioned in fig. 3 and 4.

The mass of fresh and dry matter of the calli, measured after 5 $\mathrm{w}$ of culture, is very affected by the presence of $\mathrm{NaCl}$ in the medium. Indeed, calli adapted to $150 \mathrm{mmol}$ salinity (SS150-
200 and SS150-150) are more developed in the presence of salt (150 and $200 \mathrm{mmol}$ ) than those not adapted and developed in the presence of salt (CS 200, $\mathrm{CS} 150)$ and this in the same culture medium (fig. 5). Statistical analysis shows a highly significant effect of callus type on the mass of fresh and dry matter of calli.

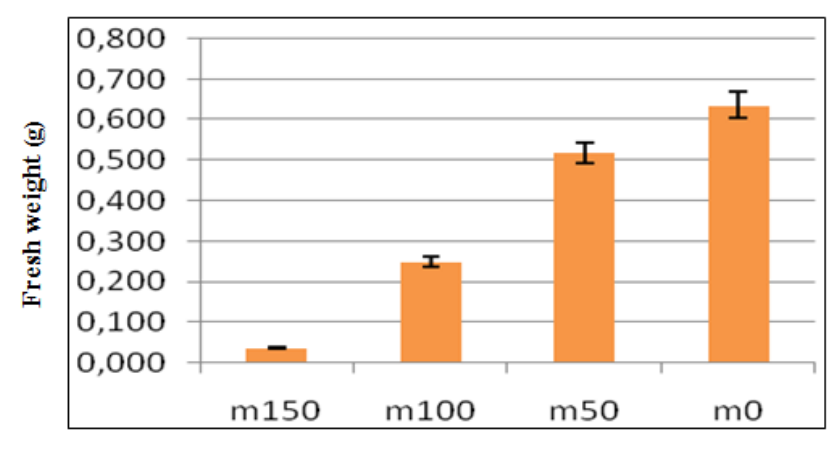

$\mathrm{NaCl}$ concentration $(\mathrm{mM} \mathrm{NaCl})$

Fig. 3: Mean effect of $\mathrm{NaCl}$ on the fresh weight of calli in four potato varieties (Désirée, Spunta, Bartina, Kondor)

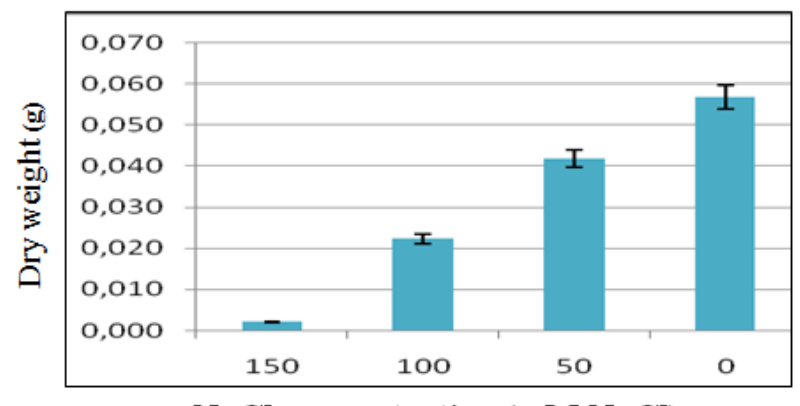

$\mathrm{NaCl}$ concentration $(\mathrm{mM} \mathrm{NaCl})$

Fig. 4: Mean effect of NaCl on dry weight of calli in four potato varieties (Désirée, Spunta, Bartina, Kondor)

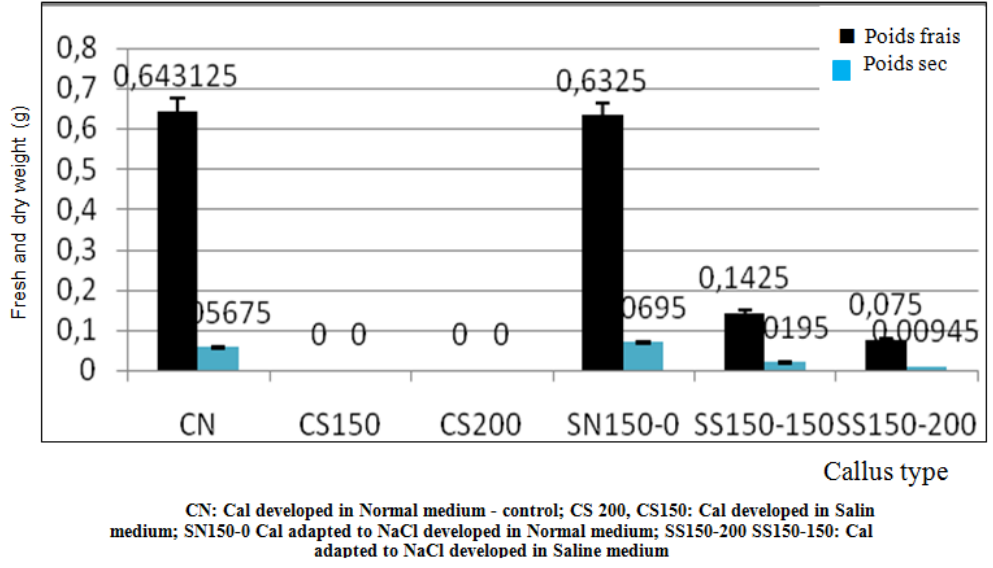

Fig. 5: Average fresh and dry weight for different types of callus in four varieties of potato (Désirée, Spunta, Bartina, Kondor)

\section{DISCUSSION OF RESULTS}

For the purpose of improving plants. The selection of plants tolerant to salinity under selective pressure, by adding a stressing agent such as $\mathrm{NaCl}$, has been used for various species, more particularly, the in vitro culture has made it possible to select salt-tolerant variants by using calli. The callus yield is dependent on several factors, 
including the nature of the explant used, the donor genotype and the culture medium used [9]. Several plants could thus be regenerated under salt stress from cell calli: wheat [10], potato [11] and Citrus [12].

Mechanisms responsible for adaptation to salinity and selection of resistant cells in laboratory conditions were investigated, however, there was not any information on the impact of salt on genetic material and creation of somaclonal variation [13]. Also, many aspects of the mechanisms that cause somaclonal variation remain undefined [6]. Part of this variation is due to gene mutations, which are transmitted sexually. These mutations do not differ essentially from those that occur spontaneously or are induced by mutagenic treatments [14]. The production of salinity-resistant calli in potatoes is largely dependent on physiological adaptation rather than causes of mutations [15].

Obtaining somaclonal variations of the salinity-resistant potato requires regeneration of plants and genetic analysis, which requires complete years. However, somaclonal variations obtained during callogenesis is an important means [16]. During the experiment, we were able to select potato calli able to grow in a culture medium supported by a high concentration of $\mathrm{NaCl}(200$ mmol), with the use of in vitro selection; callus exposure at increasing concentrations of $\mathrm{NaCl}$, with increasing concentration of $\mathrm{NaCl}$ by $50 \mathrm{mmol}$ each. Twice, for each concentration for one month for each crop.

It can be seen from the results obtained that callus formation was observed in all the $\mathrm{NaCl}$ concentrations used during the experiment, given that the increase in $\mathrm{NaCl}$ concentration in the culture medium was accompanied by a decrease in the proportion of callogenesis, this in callus not adapted to salinity. Also the percentage decrease was different from one variety to another. These results are consistent with the results of Queiros et al., [18] in potato varieties Maris, Bard and Désirée in the same concentration of $\mathrm{NaCl}$ [15]. The results also showed that calli obtained during potato breeding in the middle of increasing concentration of $\mathrm{NaCl}$ (0-50-100$150 \mathrm{mmol}$ ) change in color and morphology in function saline concentration.

The results obtained by Patnaik and Debata [17] and Queiros et al. [18] confirm that the effect of $\mathrm{NaCl}$ on calli is the appearance of necrosis [19]. We found that the adapted calli $\mathrm{SS} 150-200$ and $\mathrm{SS}_{150}-150$ are more developed than the non-saline calli $\mathrm{CS} 150$ and $\mathrm{CS} 200$ in the same concentration, which is consistent with the results of previous study [15]. We also recorded the death of all CS150 and CS2Oo calli (Cal developed directly in Salin medium). The results recorded for the dry weight of the calli are very similar to that of the fresh weight, and this for all varieties. High concentrations of $\mathrm{NaCl}$ significantly retard growth, and this is only through the low dry weight values in the 100 and $150 \mathrm{mmol} \mathrm{NaCl}$ concentrations. These results are consistent with what was obtained by Potluri and Devi Prasad [20] and Ehsanpour and Fatahian [21].

\section{CONCLUSION}

Phase control of callogenesis and adaptation to salinity by adjusting norms and optimal conditions broadens the possibility of establishing somaclonal variation based on in vitro culture of plant tissues, and with more efficient selection it becomes possible to produce new varieties of potatoes resistant to salinity and with better yield. In addition, the production of salinity-resistant potatoes has an economic advantage, especially in the arid and semiarid areas of the world, the production of salinity-resistant potatoes also paves the way for development. New unconventional programs to develop the potato crop [16].

\section{AUTHORS' CONTRIBUTIONS}

Authors contributed equally to the overall study and manuscript preparation and approved the final version of the manuscript for publication.

\section{REFERENCES}

1. Young-Min G, Tae-Won K, Min-Kyung L, Shin-Woo L. Accumulation of PrLeg, a perilla legumin protein in potato tuber results in enhanced level of sulphur-containing amino acids. Comptes Rendus Biologies. 2013;336:433-439.

2. Christophe BG, Tomader E, Jamal A, Mohamed IM, Nadia SS. NaCl ection of callus cultures of sugarcane (saccharum sp.) Tolerant to $\mathrm{NaCl}$ and their response to salt stress. Plant Cell, Tissue and Organ Culture. 2006;87:9-16.

3. Bajaj YPS. Biotechnology and 21st century potato. In Bajaj YPS. (Ed). Biotechnology in agriculture and forstry. Vol 3. Potato. Berlin: Springer-Verlag

4. Bendif $\mathrm{H}$, Adouni K, Boudjeniba M. The effect of growth regulators and explants on callus induction in four cultivars of potato (Solanum tuberosum L.). Journal of Bioressources Valorization. 2017;2 (1): 3441.

5. Larkin P, Scowcroft W. Somaclonal variation-a novel source of variability from cell cultures for plant improvement. Theoretical and Applied Genetics. 1981;60:197-214.

6. Miyao A, Nakagome M, Ohnuma $T$, Yamagata $H$, Kanamori H, Katayose Y, Takahashi A, Matsumoto T, Hirochika H. Molecular Spectrum of Somaclonal Variation in Regenerated Rice Revealed by WholeGenome Sequencing. Plant and Cell Physiology. 2012;53(1): 256-264.

7. Nistor A, Gh C, Nicoleta C, Diana K. Effect of auxine and cytokinine on callus induction in potato (Solanum tuberosum L.) explants. Agricultura-Ştiinţă şi practică. 2009;1-2:69-70.

8. Murashige T, Skoog F. A medium for rapid growth and bioassay with tobacco tissue culture. Physiologia Plantarum. 1962;15:473-497.

9. Zalc JM, Wicr HB, Kidwell KK, Steber CM. Callus induction and plant regeneration from mature embryos of a diverse set of wheat genotypes. Plant Cell Tissue and Organ Culture. 2004;76:277-281.

10. Piri K. Contribution à la sélection in vitro de plantes androgéniques de blé pour leur tolérance au $\mathrm{NaCl}$. Thèse de Doctorat, Gembloux (Belgique). 1991;168 p

11. Hannachi C. Amélioration de la tolérance de la pomme de terre (Solanum tuberosum L.) à la salinité $(\mathrm{NaCl})$ par voie biotechnologique. Thèse de Doctorat, Gand (Belgique). 1996;152 p

12. Beloualy N, Bouharmont J. Amélioration de la tolérance à la salinité par sélection in vitro chez deux porte-greffes de Citrus. In: Le progress génétique passe-t-il par le repérage et l'inventaire des gènes? Ed. AUPELF-UREF John Libbey Eurotext, Paris. 1993;301-304. 
13. Luttis S, Kinet J, Bouharmont J. Somaclonal variation in rice after two successive cycles of mature embryo derived callus culture in the presence of $\mathrm{NaCl}$. Biologia Plantrarum. 2001;44(4): 489-495.

14. Bouharmont J. Utilisation de la variation somaclonale et de la sélection in vitro à l'amélioration du riz. Université catholique de Louvain, 1348 Louvain-laNeuve, Belgique, 1991;Pp. 1-8.

15. Sabbah S, Tal M, Development of callus and suspension cultures of potato resistant to Nacl and mannitol and their response to stress. Plant Cell, Tissue and Organ Culture. 1990;21:119-128.

16. Ochatt SJ, Marconi PL, Radice S, Arnozis PA, Caso $\mathrm{OH}$. In vitro recurrent $\mathrm{NaCl}$ ection of potato: production and characterization of salt tolerant cell lines and plants. Plant cell, Tissue and Organ Culture. 1999;55:1-8.
17. Patnaik J, Debata BK. In vitro $\mathrm{NaCl}$ ection of $\mathrm{NaCl}$ tolerant callus lines of Cymbopogon martinii (roxb.) WATS, Plant Science. 1997;124:203-210.

18. Queiros F, Fidalgo F, Santos I, Salema R. In vitro $\mathrm{NaCl}$ ection of salt tolerant cell lines in Solanum tuberosum L. Biologia plantarum. 2007;51(4) 728734 .

19. Stephen $\mathrm{FC}$, Indra $\mathrm{KV}$. $\mathrm{NaCl}$ ection and characterization of $\mathrm{NaCl}$ tolerant cells from embryogenic cultures of Pennisetum purpureum schum. (Napier grass), Plant Science Letters. 1984;37:157-164.

20. Potluri Sasikala DP, Devi Prasad PV. Salinity effects on in vitro performance of some cultivars of potato. Revista Brasileira de Fisiologia Vegetal. 1994;6(1): 1-6.

21. Ehsanpour AA, Madani S, Hoseini M. Detection of somaclonal variation in Potato callus induced by Uv-c radiation Using RAPD-PCR, Gen. Appl. Plant Physiology. 2007;33 (1-2): 3-11. 